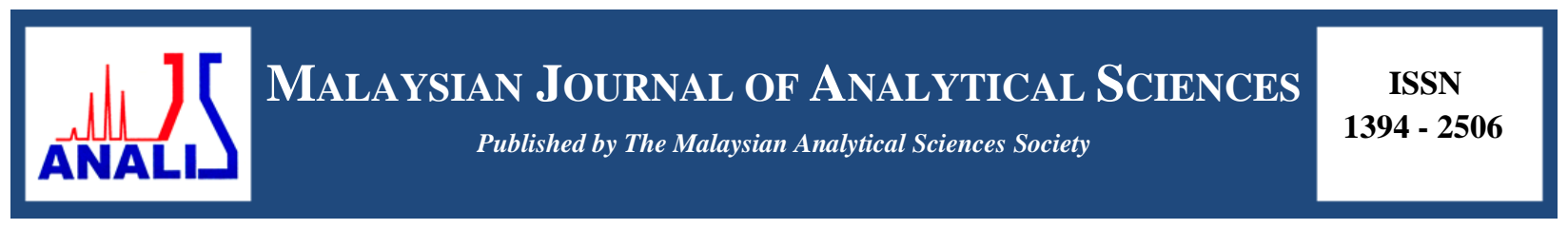

\title{
ISOLATION, PURIFICATION AND IDENTIFICATION OF MICROALGAE FROM COAL-FIRED POWER PLANT ENVIRONMENT
}

\author{
(Pemencilan, Penulenan dan Identifikasi Mikroalga daripada Persekitaran Loji Janakuasa Arang \\ Batu)
}

\author{
Muhammad Nazry Chik ${ }^{1}$, Liyana Yahya ${ }^{1}$, Kamrul Fakir Kamarudin ${ }^{2}$, Ding Gong Tao ${ }^{2}$, Mohd Sobri Takriff ${ }^{2 *}$ \\ ${ }^{1}$ Emission and Waste Management Technology Group, \\ TNB Research Sdn Bhd, No 1, Lorong Air Hitam, Kawasan Institusi Penyelidikan, 43000 Kajang, Selangor, Malaysia \\ ${ }^{2}$ Department of Chemical and Process Engineering, Faculty of Engineering and Built Environment, \\ Universiti Kebangsaan Malaysia, 43600 UKM Bangi, Selangor, Malaysia \\ *Corresponding author: sobritakriff@ukm.edu.my
}

Received: 21 October 2015; Accepted: 14 June 2016

\begin{abstract}
Carbon capture and storage (CCS) through biological approach has attracted much attention as global warming and climate change issue becomes a worldwide agenda. Energy production industry from coal in Malaysia produced 50.661 million metric tons of carbon dioxide in 2012, and the trend showed it will keep increasing year by year. CCS through biological approach can be done by microalgae which are versatile microorganism which perform photosynthesis process that can store $\mathrm{CO}_{2}$ in the biomass form. In this study, microalgae strains were isolated from the native environment nearby a coal-fired power plant, where samples were collected in different canal in which pre-treated flue gases are discharged. The microalgae strains were identified by both morphological and molecular approaches. Result from 18s rRNA gene sequencing showed that the isolated strains is Chlorella sp. with similarity $99 \%$ with Chlorella sp. SAG 211-18. The identified strains of microalgae then cultivated with three concentration of $\mathrm{CO}_{2}$ (ambient air, 1\% and 5\%) and the growth rate showed 0.4017 day $^{-1}, 0.5752$ day $^{-1}$ and 0.4427 day $^{-1}$ respectively. Different concentration of $\mathrm{CO}_{2}$ (ambient air, $1 \%$ and $5 \%$ ) showed that the isolated strains yielded $1.005 \mathrm{gL}^{-1}$, $1.101 \mathrm{gL}^{-1}$ and $1.035 \mathrm{gL}^{-1}$ respectively. This study also showed that with different concentration of $\mathrm{CO}_{2}$, the sequestration rate is ranging from $1 \%$ to $4.3 \%$.
\end{abstract}

Keywords: microalgae, isolation, purification, DNA sequencing

\begin{abstract}
Abstrak
Pemerangkapan dan penyimpanan karbon (CCS) melalui pendekatan biologi telah menarik minat pengkaji disebabkan masalah pemanasan dan perubahan iklim global. Pada tahun 2012 sahaja, Malaysia telah menghasilkan 50.661 juta ton metrik karbon dioksida hasil daripada penghasilan tenaga yang bersumberkan arang batu, dan tahun demi tahun penghasilan karbon dioksida dijangkakan akan terus meningkat. Pemerangkapan dan penyimpanan karbon melalui pendekatan biologi boleh dilakukan oleh mikroalga yang merupakan mikroorganisma unggul di mana ianya berupaya menjalankan proses fotosintesis dalam menukarkan karbon dioksida ke dalam bentuk biojisim. Dalam kajian ini, mikroalga dipencilkan daripada habitat asal yang merupakan terusan bagi air penyejuk untuk stesen janakuasa arang batu. Mikroalga yang diperoleh, dikenalpasti menggunakan kaedah pengecaman secara morfologi dan molekul. Hasil keputusan pengenal pastian molekul menggunakan kaedah penjujukan genom 18s rRNA mendapati, mikroalga yang berjaya dipencilkan adalah Chlorella sp. yang mempunyai persamaan sehingga $99 \%$ dengan Chlorella sp. SAG 211-18. Mikroalga yang telah menjalani proses identifikasi kemudiannya dikultur menggunakan 3 kepekatan karbon dioksida yang berbeza $\left(\mathrm{CO}_{2}\right.$ pada udara persekitaran, $\mathrm{CO}_{2} 1 \%$ dan $\left.\mathrm{CO}_{2} 5 \%\right)$ dan hasil menunjukkan kadar pertumbuhan masing-masing adalah 0.4017 hari $^{-1}, 0.5752$ hari $^{-1}$, dan 0.4427 hari ${ }^{-1}$. Pada kepekatan $\mathrm{CO}_{2}$ yang berbeza $\left(\mathrm{CO}_{2}\right.$ pada udara persekitaran, $\mathrm{CO}_{2} 1 \%$ dan $\mathrm{CO}_{2} 5 \%$ ), hasil biojisim yang terkumpul daripada pengkulturan mikroalga masing-masing
\end{abstract}




\section{Muhammad Nazry et al: ISOLATION, PURIFICATION AND IDENTIFICATION OF MICROALGAE FROM COAL-FIRED POWER PLANT ENVIRONMENT}

adalah $1.005 \mathrm{gL}^{-1}, 1.101 \mathrm{gL}^{-1}$ dan $1.035 \mathrm{gL}^{-1}$. Kajian juga menunjukkan pada kepekatan $\mathrm{CO}_{2}$ yang berbeza, kadar pemerangkapan karbon dioksida adalah pada kadar $1 \%$ sehingga $4.3 \%$.

Kata kunci: mikroalga, pemencilan, penulenan, penjujukan DNA

\section{Introduction}

Studies on microalgae mostly ranging around the ability of biomass accumulation for food additive, colouring and high value product such as anti-oxidant. This research field has been widely explore in the previous decade and the exploration on other branches of microalgae utilization has taken place recently due to environmental concern especially regarding to global warming due to the rising of carbon dioxide produce by human activities [1 - 4]. Microalgae are a robust microorganism which can survive and thrive in different mode; photo-autotrophic, mixotrophic, heterotrophic and some mixture of complex metabolism to survive in harsh culture condition [5-8]. The ability of microalgae to conduct photo-autotrophic showed that microalgae has the potential to be applied in the process of carbon capture and storage (CCS) [9].

As the world progress and develop in becoming more advanced society, the energy demands around the world keep increasing year by year. Energy is a vital factor for progress to the advanced society since large scale activities such as urbanization, industrial activities; plantation, mining and livestock farming are becoming into commercial scale and subsequently demand higher energy input. Most of the world energy demand is supplied by fossil fuels burning power plants, which are using different sources of fossil fuel such as coal, natural gases, and petroleum based product [10, 11]. According to a report from Suruhanjaya Tenaga Malaysia, there are 4 main sources of fossil fuels are used as primary energy supply in Malaysia. The sources are crude oil, petroleum product, natural gas and, coal and coke [12]. All this generates $\mathrm{CO}_{2}$, carbon monoxide and methane which is the main contributor to the global warming effect since these gases trap the heat and has increased the world temperature in the range of $1^{\circ}$ to $2^{\circ} \mathrm{C}$ over the past decade. The only renewable source of energy used by Malaysia from 1978 until 2010 was hydropower energy. However since the year 2011, biodiesel, biomass, biogas and solar has contribute small portion of energy supply which around 115, 183, 4, 11 ktoe respectively for year 2012 [12].

Before the pre-industrial era, the $\mathrm{CO}_{2}$ concentration in the air was recorded below $300 \mathrm{ppm}$. Since then, the concentration of $\mathrm{CO}_{2}$ has steeply increased and has causing the rise of global temperature. According to the report from Mauna Loa Observatory (NOAA-ESRL), the atmospheric $\mathrm{CO}_{2}$ concentration on June 2015 was recorded around 402.8 ppm [13]. Compare to the previous years of June 2014 and 2013, the concentration of $\mathrm{CO}_{2}$ was recorded at $401.15 \mathrm{ppm}$ $398.58 \mathrm{ppm}$. The effect of higher $\mathrm{CO}_{2}$ concentration has been affecting the human life since breaking hot temperature during the summer season has been recorded around the world [14]. The effect of global warming has also affecting Malaysia; where for the past two years Malaysia had experienced hot temperature well above the normal average temperature.

Tenaga Nasional Berhad (TNB) is the largest utilities company in Malaysia and supplies most of the electricity to Malaysian Peninsular and State of Sabah through the Malaysian National Grid. The main energy source for electricity power generation for TNB is coal and coke which is relatively cost effective, coupling with state of the art technology in reducing $\mathrm{CO}_{2}$ emission with collaboration with Alstom S. A. from France [15]. However, the emission of $\mathrm{CO}_{2}$ is still an 'Achilles Heels' for this system and thus, new approach has been embarked to counter and reduce more on $\mathrm{CO}_{2}$ emission. The available solution is though CCS using microalgae [16, 17]. Thus, this paper reports on the works and progress of isolation of microalgae in the native environment near to the coal-fired power plant [18]. This works covers the isolation, morphological and molecular identification of isolated microalgae.

\section{Isolation of microalgae}

\section{Materials and Methods}

Samples were collected from the canal of cooling water from Stesen Janakuasa Sultan Azlan Shah, Manjung Perak, west coast of Malaysian Peninsular, 4' 9' 31.158' S latitude and 100 38' 30.3396" E longitude. The power plant uses coal as the fuel and is among the major power generation plant in Malaysia, having installed capacity of 3 units of 700 MW. The canals form a discharge point of sea water used in the steam cooling process in the upstream. Besides steam cooling, the sea water also was used as jet water spray as to discard debris, being injected with hypochlorite as 
disinfectant and also sprayed as part flue gas desulphurisation process before finally aerated (air bubbled) in the canals before being discharged to the open sea. Thus, any microalgae species that are available from the sea water intake shall experience varying degrees of hydrodynamic stresses, disinfection and temperature difference based on the process described above, and thus any ones which found dominant in the canals shall be the ones who are robust enough to survive further in bioreactors performing carbon biofixation exposed to actual power plant's flue gas. Collections of samples were conducted during the noon time where the suspected source areas of microalgae were exposed to sunlight at the maximum light density. The light intensity during the afternoon period can reach as high as 60,000 Lux during the sunny day. Microalgae which survived in photo-autotrophic mode tend to float on the surface area to capture energy from the sun for photosynthesis process.

The samples from the source were added with F/2 Medium, TNBR medium and Bold Basal's Medium (BBM) respectively with ratio of 1:1 (volume/volume) to promote growth of microalgae available in the targeted samples. The samples were maintained in $50 \mathrm{~mL}$ centrifuge tube, at room temperature at $28{ }^{\circ} \mathrm{C}$ and kept with continuous light exposure at 12,000 lux by $50 \mathrm{~W}$ fluorescent daylight type lamps. The samples were monitored daily to determined suitable medium for isolation as well as the growth curves of microalgae.

The samples were maintained and observed under microscope (Cole-Parmer, USA) for isolation and morphological screening purpose. Microscope used is equipped with light chamber, measuring grid embedded with the software provided by Motic Image Plus 2.0 and image capturing camera. Observation of microalgae growth in the liquid medium was continued with plating method by using the respective medium with $1.25 \%$ agar plate. In the parallel of liquid medium and $1.25 \%$ agar cultivation, the growth of microalgae were measured by biomass accumulation, cell density and amounts of colonies on the plate respectively.

\section{Cultivation}

Samples of microalgae which has been promoted by F/2 medium, TNBR medium and BBM medium were observed and screened morphologically and has been done by comparing to the online catalogue provided by University of Texas, The Culture Collection of Algae at Goettingen University (international acronym SAG). Morphological identification was done by determining the characteristic of isolated microalgae; size, availability of membrane wall and flagella, and the shape of chloroplast.

After growth of microalgae were observed, cultures of microalgae were transferred into $250 \mathrm{~mL}$ Duran Schott Bottle with F/2 medium, TNBR medium and BBM medium respectively with 10 percent of inoculums from the source of microalgae. To promote more growth, cultured microalgae were sparged with air to avoid settling as well as providing the $\mathrm{CO}_{2}$ from ambient air. Cultivation of microalgae was then continued until single/pure strain achieved in the culture system. Single/Pure strains of microalgae was achieved by continuous plating using F/2, TNBR, and BBM Medium agar. The pure strains were then re-cultivated into F/2 medium and TNBR medium liquid solution for inoculum preparation as well as for the molecular identification purpose. Microalgae biomass were collected daily to plot the growth curve of microalgae and calculate the specific growth rate $\left(\mu_{\max }\right)$. The $\mu_{\max }$ value was determined by using the MathLab 9.0 version software with application of Logistic Modelling. Generally the growth curve of microalgae is in the sigmoid shape and previous studies has successfully fit the original data with the Logistic Model [19, 20, 21]. Thus, in this study, Logistic Model was used to fit the data and determined the value of $\mu_{\max }$. The $\mu_{\max }$ values were calculated using Equation 1 below:

$$
X=\frac{X o X \max \cdot e^{\mu} \max t}{X \max -X o+X o e^{\mu_{\max } t}}
$$

where $\mathrm{X}$ is the value of predicted biomass achieved by the Logistic Model, $X_{0}$ is the initial biomass achieved during the experimental set up, and $X_{\max }$ is the maximum biomass achieved while $t$ is the time take during the experiment.

\section{Molecular identification}

Single/Pure strain of microalgae achieved in isolation process was used in molecular identification. Wet biomass of microalgae were collected and genomic DNA was extracted from it by using liquid nitrogen. Liquid nitrogen is a good agent for extraction due to the low temperature properties which it has boiling point at $-196{ }^{\circ} \mathrm{C}$ and this will freeze and 
crystalize the microalgae cells in the biomass instantly. Wet biomasses from cultivated microalgae were soaked into liquid nitrogen and homogenized with mortar and pestle for initial steps in breaking the cell wall of microalgae in order to extract the genomic DNA (gDNA). Next steps in achieving gDNA, extraction kit from Promega containing nuclei lysis solution, protein precipitation solution, isopropanol, ethanol and RNase solution was used according to manual from the manufacturer. Biomass achieved was then extracted using plant extraction kit by Promega Wizard Genomic DNA Purification Kit [22]. 18s rRNA genes Polymeric Chain Reaction (PCR) amplified using forward (50 TACTGTGAAACTGCGAATGGCTC 30) and reverse (50 TGATCCTTCCGCAGGTTCACCTA 30) primer was used in this process [23, 24]. The primer was design by FirstBase Sdn Bhd. Purified and single cultured microalgae from the coal-fired power plant were further identified using molecular identification.

PCR products were sequenced by Life Technologies (China). The sequenced products were compared with NCBI data bank using the BLAST Program. (NCBI BLAST, USA). Top ten similar results were achieved and compared for the similarity in the percentage value.

\section{Carbon dioxide sequestration}

Single/Pure strain of microalgae were then cultivated in 2L Schott Duran Bottle with 3 outlets on the top of the cap; 1) used for $\mathrm{CO}_{2}$ sparging inlet point, 2) used for $\mathrm{CO}_{2}$ sampling outlet, 3) used for secondary outlet as shown in Figure 1. Different $\mathrm{CO}_{2}$ concentration at ambient air condition, $1 \% \mathrm{CO}_{2}$ and $5 \% \mathrm{CO}_{2}$ were tested to determine the preliminary result for $\mathrm{CO}_{2}$ sequestration rate. $\mathrm{CO}_{2}$ analyzer (Quantek, Mode1902D) was used in this run where infra-red sensor read the $\mathrm{CO}_{2}$ concentration continuously. Continuous data were collected using data logger.

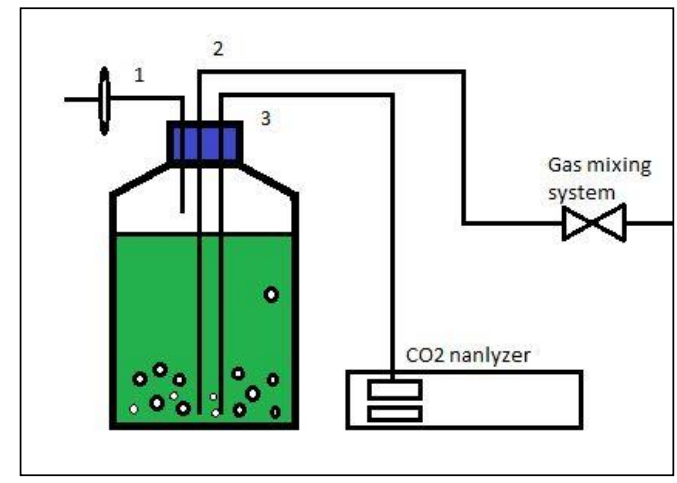

Figure 1. Schematic of cultivation in 2L Schott Duran for $\mathrm{CO}_{2}$ sequestration experiments; 1) air outlet, 2) gas mixing system inlet and 3) $\mathrm{CO}_{2}$ analyzer outlet

\section{Isolation of microalgae}

\section{Results and Discussion}

The samples that were collected have a $\mathrm{pH}$ ranging around 7.0 to 8.5. This alkalinity can be explained due to the sample of the water; usage water containing isolated microalgae source was used as a cooling water for the coal-fired power plant which ash from the burning coal contribute to this phenomena [25, 26].

Isolation process of microalgae with both liquid medium and $1.25 \%$ agar plate showed that microalgae only survived in the F/2 Medium and TNBR medium. Isolation using BBM in liquid medium and agar plate showed lower growth in liquid medium cultivation, while in agar plate there was no colony detected. This can be explained due to higher salinity of F/2 medium and TNBR medium which both used artificial seawater as a component of the medium, while BBM has much lower salinity [27]. Microalgae which has been collected from the source has been exposed and acclimatized to the higher salinity environment for long period of time. From this finding, it can be determined that F/2 medium and TNBR medium is the most suitable medium compare to BBM. Thus, only F/2 medium and TNBR medium was chosen for the next experiment on purification and identification process. Besides sea water as the main 
factor for higher salinity, higher alkalinity of the water at the source of isolation place was effected by the ash produced by the coal-fired power plant. Result also showed that at $\mathrm{pH}$ more than 7, isolated microalgae start to pick up the higher phase of growth.

\section{Cultivation and morphological identification of microalgae}

Isolated and purified microalgae were cultivated in F/2 medium and TNBR medium. Growth profiles of the microalgae were determined by biomass accumulation in both F/2 and TNBR medium. Figure 2 showed the growth curve of isolated microalgae in TNBR medium (ambient air, $1 \%$ and $5 \% \mathrm{CO}_{2}$ ) and Figure 3 showed the growth curve of isolated in $\mathrm{F} / 2$ medium (ambient air and $5 \% \mathrm{CO}_{2}$ ). From the growth profile, the specific maximum growth rate $\left(\mu_{\max }\right)$ of each cultivation was determined by using MathLab 9.0 version software. Logistic model was used for the curve fitting in for the microalgae growth curve. Population and productivity of microalgae has been widely using Logistic Model for curve fitting since the Logistic equation often represent growth data better than the exponential one [21]. The value of $\mu_{\max }$ was calculated according to the Equation 1.

Result of $\mu_{\max }$ showed that TNBR medium promote better growth by producing higher $\mu_{\max }$ value compare to $\mathrm{F} / 2$ medium. By using TNBR medium the value of $\mu_{\max }$ achieved were 0.4046 day $^{-1}, 0.4288$ day $^{-1}$ and 0.4908 day $^{-1}$ for ambient air, $1 \% \mathrm{CO}_{2}$ and $5 \% \mathrm{CO}_{2}$ respectively. Result of $\mu_{\max }$ from $\mathrm{F} / 2$ medium achieved were 0.2784 day $^{-1}$ and 0.3937 day $^{-1}$ for ambient air and $5 \% \mathrm{CO}_{2}$ respectively. Higher value of $\mu_{\max }$ achieved by TNBR medium cultivated microalgae was due to high nutrients content compare to the F/2 medium. TNBR medium used in this experiment is an optimized medium from $\mathrm{F} / 2$ medium.
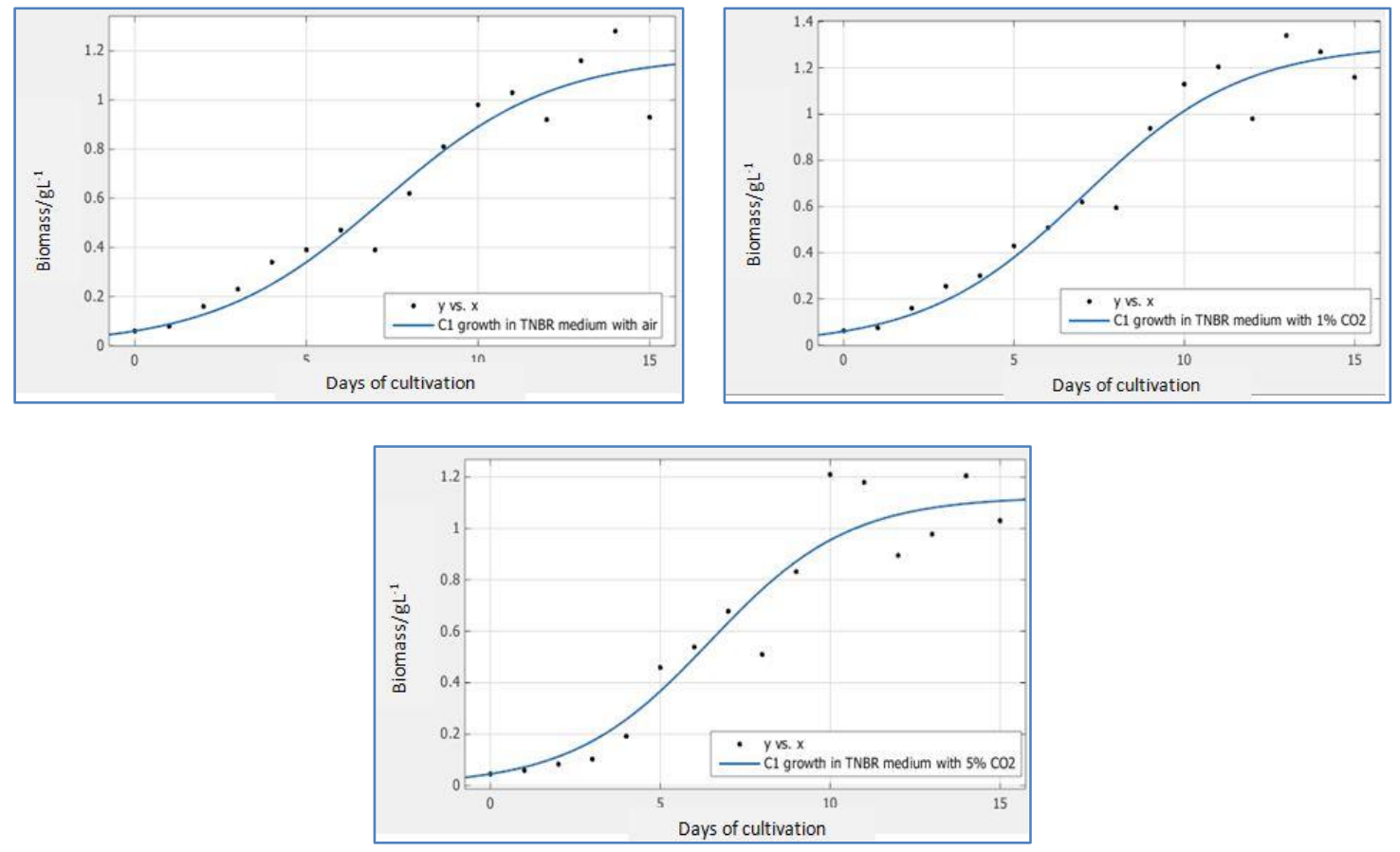

Figure 2. Growth curve of isolated Chlorella sp. with TNBR medium at ambient air, $1 \%$ and $5 \% \mathrm{CO}_{2}$ 

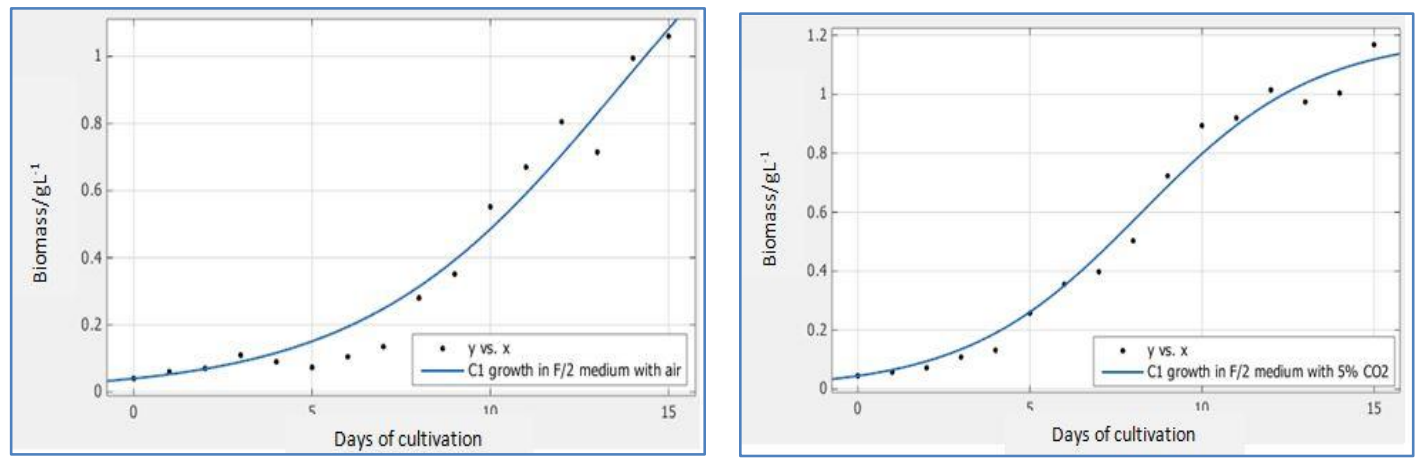

Figure 3. Growth curve of Chlorella sp. with $\mathrm{F} / 2$ medium at ambient air, and $5 \% \mathrm{CO}_{2}$

Morphological identification was conducted by characterization of microalgae. Under microscopic observation, the size of the purified microalgae is ranging around $4.24 \sim 10 \mu \mathrm{m}$ with the area around $56.48 \mu \mathrm{m}^{2}$. The visible characteristic that can be observed was round shape with transparent outer membrane. All the purified microalgae showed round or ellipsoidal shape with a thin layer of membrane without any extension of flagella. The purified microalgae also have gridle shape of chloroplast. The chloroplast occupies most of periphery except for the cell ends. It also has the tendency to clump together into big colonies with a slow movement [28]. By assessment of all the morphological characteristic of the isolated microalgae, the suspected species was Chlorella sp. Figure 4 shows the morphological view under 400x magnifications with comparison from Chlorella sp. from UTEX (1000x magnification). Microalgae Chlorella species is blue-green algae which is belongs to phylum chlorophyta division. Most of Chlorella species survived and cultivated in freshwater conditions. However, several reports and studies on isolation showed the versatility and the availability of Chlorella species to adapt and survive in marine environment $[29,30]$. Other result from NCBI also showed that several microalgae which were isolated from South China Sea were confirmed to be Chlorella species. Thus, it make the morphological identification of this experiment valid to be Chlorella sp. Further identification was confirmed with molecular identification with genes sequencing.
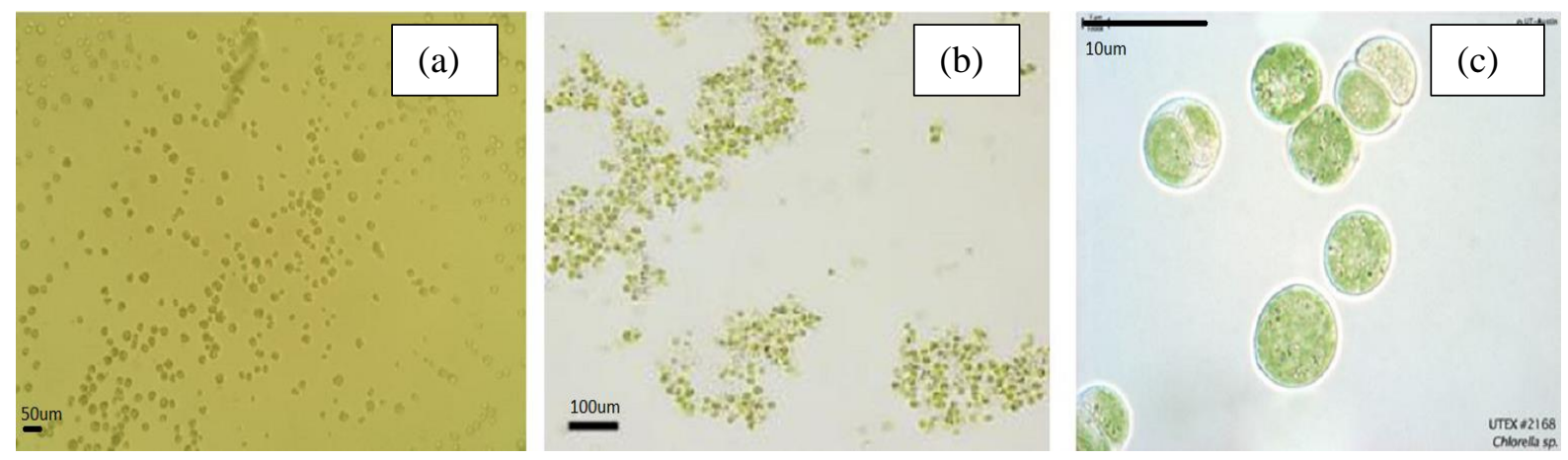

Figure 4. Morphological observation of (1)isolated microalgae (40x magnification) with comparison from (2) Imase et al. and (3) Chlorella sp. of UTEX (1000x magnification) [31]

\section{Molecular identification of microalgae}

Extraction and Purification of gDNA was conducted with a procedure suggested by the manual form the manufacturer (Promega) as mention in methodology section. Extracted gDNA then amplified using PCR with 18s rRNA primer before it is sequenced. Figure 5 showed that PCR product were run into gel for confirmations before the PCR product undergoes sequencing process. 


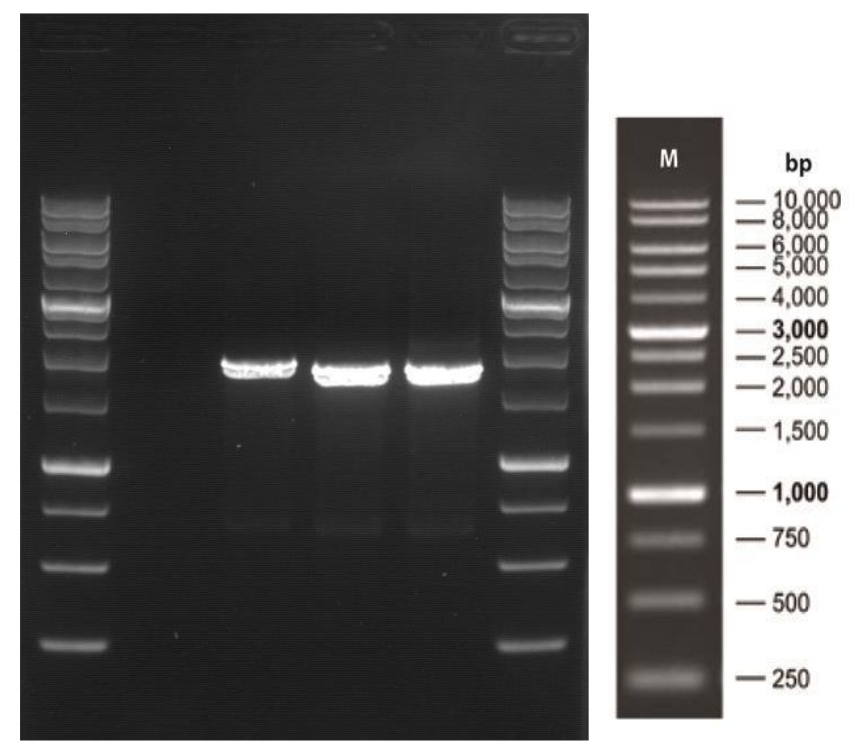

Figure 5. Result of PCR gel run on the ladder. Negative (-) was the PCR non-template control (water only), and positive $(+)$ is positive control using DNA extracted from human blood sample as a template

PCR product which has been successfully sequenced has the size of 1792bp. Full sequenced by 18s rRNA gave full sequenced of the isolated microalgae. Full sequenced obtained from sequencing process was blast into the NCBI BLAST software to compare the obtained result with the gene bank for the identification purpose. Top ten hits blast result were observed and showed in the Figure 6 in the form of phylogenetic tree where most of the result showed the similarity to the isolated microalgae from the coal-fired power plant. Result from the list of showed seven out of ten confirm up to $99 \%$ that an isolated, purified and sequenced microalgae is Chlorella sp. Thus, from molecular result plus with similar characteristic by morphological identification, it was confirm that isolated microalgae were Chlorella sp.

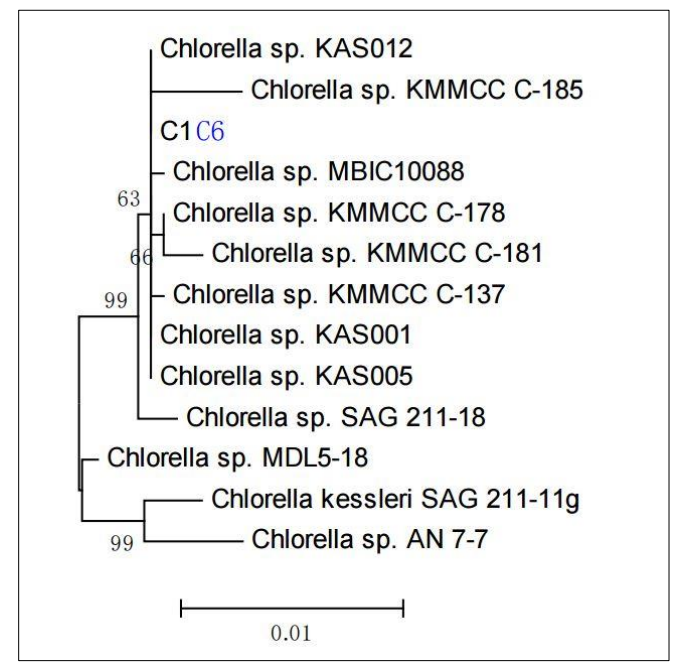

Figure 6. Top ten of phylogenetic tree of isolated microalgae; Chlorella sp. from NCBI genes bank database 


\section{Muhammad Nazry et al: ISOLATION, PURIFICATION AND IDENTIFICATION OF MICROALGAE FROM COAL-FIRED POWER PLANT ENVIRONMENT}

Among the similar result from the phylogenetic tree, Chlorella sp. SAG 211-18 showed similarity almost to $99 \%$. According to the data base from the Experimental Phycology and Culture Collection of Algae at the University of Goettingen (EPSAG), this microalgae which was formally called as Chlorella sorokiniana was isolated from Sweden. The source of the microalgae was from freshwater habitat which is surrounded by the Baltic Sea. Similar to the isolated microalgae in this study, the species was exposed to harsh environment surrounding of coal-fired power plant and closed proximity to the marine environment.

\section{$\mathrm{CO}_{2}$ sequestration}

Isolated native microalgae were tested for its capability in performing carbon capture and storage (CCS) by sequestration of $\mathrm{CO}_{2}$. Result from the $\mu_{\max }$ value, showed that TNBR medium gave better result in the growth profile of microalgae. Thus in the $\mathrm{CO}_{2}$ sequestration test, TNBR medium was used as the main medium for microalgae cultivation. $\mathrm{CO}_{2}$ was supplied by mixing the $95 \%$ purity of $\mathrm{CO}_{2}$ with compress air. At $1 \%$ and $5 \%$ concentration, $\mathrm{CO}_{2}$ were fixed for the run and the percentage was set using volume/volume ratio (v/v). Results of $\mathrm{CO}_{2}$ sequestration by isolated Chlorella sp. are shown in Figure 7a and 7b. Result from $1 \%$ and 5\% of $\mathrm{CO}_{2}$ input showed that isolated Chlorella sp. manage to sequester $\mathrm{CO}_{2}$ up to $4.3 \%$ and $4.5 \%$ respectively. Comparison with previous result showed that marine Chlorella sp. showed lower $\mathrm{CO}_{2}$ sequestration uptake compare to the Chlorella sp. which has been reported previously which is ranging from the $15 \%$ to $30 \%$ ability to absorb the $\mathrm{CO} 2$ into the biomass form [18, 32]. Higher uptake $\mathrm{CO}_{2}$ can be achieved in optimization of higher $\mathrm{CO}_{2}$ input and aeration rate.
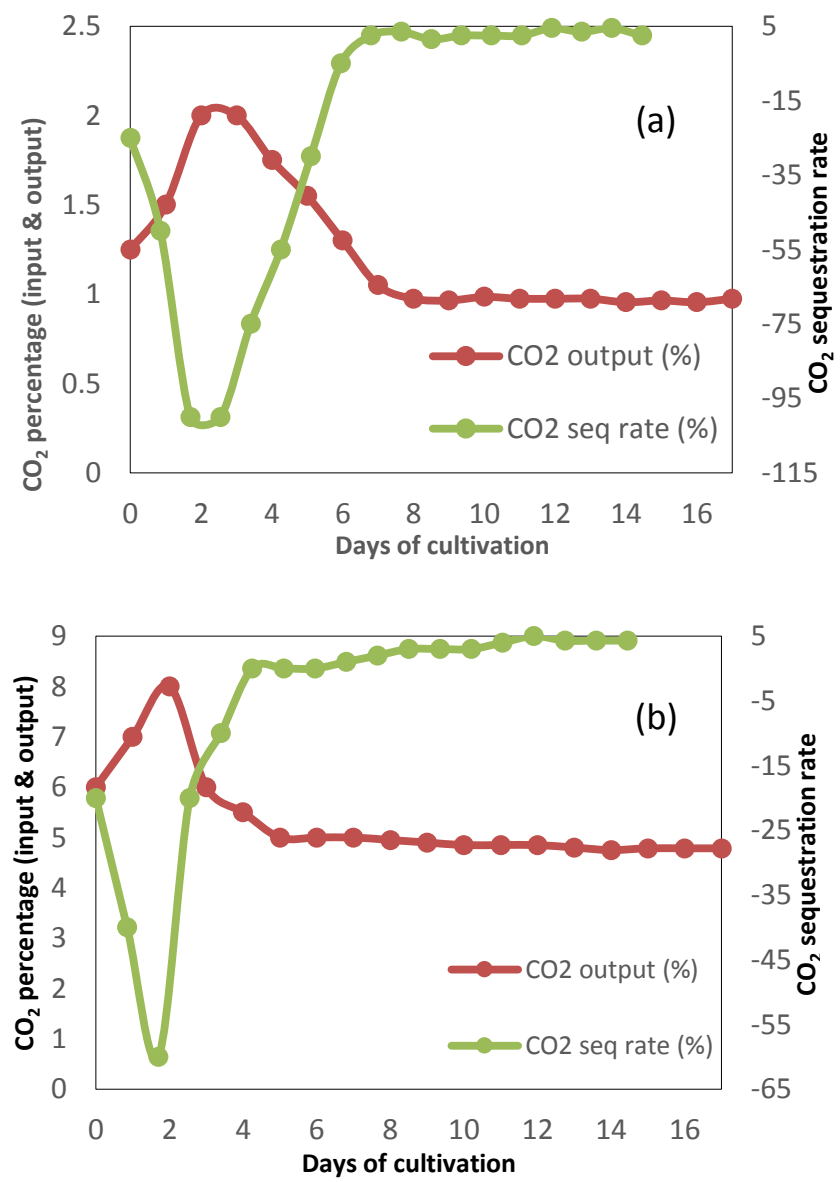

Figure 7. Result of Chlorella sp. in performing $\mathrm{CO}_{2}$ sequestration at a) $1 \% \mathrm{CO}_{2}$ concentration and b) $5 \% \mathrm{CO}_{2}$ concentrations, repectively 
However, higher accumulation of $\mathrm{CO}_{2}$ in the first phase of algae culturing has produce a spike in the beginning of 5 to 7 days of cultivation periods. These phenomena can be explained by the lag phase of microalgae which has lower growth at the initial stage. Higher accumulation at the initial stage can be reduced with better inoculation process which is inoculums at the exponential phase are used for every single run. Acclimatization of microalgae to higher $\mathrm{CO}_{2}$ concentration will also contribute to higher sequestration rate and reduce the accumulation of $\mathrm{CO}_{2}$ in the initial phase.

The spike reduction with time of cultivation has shown that microalgae has the potential that can be tapped to produced biomass even with higher $\mathrm{CO}_{2}$ concentration compare to the ambient air and this biomass later can be utilized in other product that can contribute to more capital as the world moving forward for the generating waste from the wealth. Thus, the isolated Chlorella sp. showed significant result in CCS by converting the $\mathrm{CO}_{2}$ supplied into the biomass form.

\section{Conclusion}

Chlorella sp. has been isolated from the native environment of Stesen Janakuasa Sultan Azlan Shah. Through morphological and molecular identification it has been confirmed that isolated strain is Chlorella sp. which has similar sequenced to Chlorella sorokinia from SAG 211-18. Isolated Chlorella sp. also showed that for higher growth it more favor the TNBR medium by achieving higher $\mu$ max value compare to the F/2 medium. At higher $\mathrm{CO}_{2}$ percentage, isolated Chlorella sp. showed that it has potential in reducing the $\mathrm{CO}_{2}$ while still survive and accumulate the biomass. Therefore, isolated Chlorella sp. can be used and explored more on its $\mathrm{CO}_{2}$ tolerance at higher $\mathrm{CO}_{2}$ concentration and can be utilized to biofixation of $\mathrm{CO}_{2}$ from coal-fired power plant, which contributes to a reduction in global warming.

\section{Acknowledgement}

The authors would like to acknowledge and thank TNB Research Technical Board Committee for approving a seed fund no. TNBR/SF0157/2014 and UKM in supporting the research financially and educationally between 2014 and 2015. Also appreciating the Management of TNB Janamanjung Sdn. Bhd. for their co-operation and support.

\section{References}

1. Certik, M. and Shimizu S. (1999). Biosynthesis and regulation of microbial polyunsaturated fatty acid production. Journal of Bioscience and Bioengineering., 87(1): 1 - 14.

2. Hama, S. and Kondo, A. (2012). Enzymatic biodiesel production: An overview of potential feedstocks and process development. Bioresource Technology, 135: 386 - 395.

3. Fujii, K. (2012). Process integration of supercritical carbon dioxide extraction and acid treatment for astaxanthin extraction from a vegetative microalga. Food Bioproducts Processing, 90(4): 762 - 766.

4. Kao, C.Y., Chiu, S. Y., Huang, T. T., Dai, L., Wang, G. H, Tseng, C. P., Chen, C. H. and Lin, C. S. (2012). A mutant strain of microalga Chlorella sp. for the carbon dioxide capture from biogas. Biomass and Bioenergy, 36: 132 - 140.

5. Liang, Y., Sarkany, N. and Cui, Y. (2009). Biomass and lipid productivities of Chlorella vulgaris under autotrophic, heterotrophic and mixotrophic growth conditions. Biotechnology Letters, 31(7): 1043 -1049.

6. Perez-Garcia O, Escalante F. M. E., De-Bashan L. E. and Bashan Y. (2011). Heterotrophic cultures of microalgae: Metabolism and potential products. Water Research, 45: 11 - 36.

7. EL-Sheekh, M. M., Bedaiwy, M. Y., Osman M. E. and Ismail, M. M. (2012). Mixotrophic and heterotrophic growth of some microalgae using extract of fungal-treated wheat bran. International Journal of Recycling Organic Waste in Agriculture, 1(1): 1 - 9.

8. Wensel, P., Helms, G., Hiscox, B., Bavis, W. C., Kirchoff, H., Bule, M., Yu, L. and Chen S. (2014). Isolation, characterization, and validation of oleaginous, multi-trophic, and haloalkaline-tolerant microalgae for two-stage cultivation. Algal Research, 4: 2 - 11.

9. Pires, J. C. M., Alvim-Ferraz, M. C. M., Martins, F. G. and Simões M. (2012). Carbon dioxide capture from flue gases using microalgae: Engineering aspects and biorefinery concept. Renewable and Sustainable Energy Reviews, 16(5): 3043 - 3053. 
10. Radmann, E. M., Camerini, F. V., Santos, T. D. and Costa, J. A. V. (2011). Isolation and application of $\mathrm{SO}_{\mathrm{X}}$ and $\mathrm{NO}_{\mathrm{x}}$ resistant microalgae in biofixation of $\mathrm{CO}_{2}$ from thermoelectricity plants. Energy Conversion Management, 52(10): 3132 - 3136.

11. de Morais M. G. and Costa J. A. V. (2007). Isolation and selection of microalgae from coal fired thermoelectric power plant for biofixation of carbon dioxide. Energy Conversion Management, 48(7): 2169 - 2173.

12. Malaysia Energy Information Hub (2013). Primary Energy Supply (Ktoe). Putrajaya, Malaysia.

13. $\mathrm{CO}_{2}$ now.org. Earth's $\mathrm{CO}_{2}$ home page. Access from http://co2now.org/.

14. Tans P., Keeling R. (2015). Global Greenhouse Gas Reference Network. Mauna Loa http://www.esrl.noaa.gov/ $\mathrm{gmd} / \mathrm{ccgg} /$ trends/. Accessed online [July 13, 2015].

15. Alstom S. A. (2013). Case Study: Steam Product Solutions. Manjung Unit 4 - Malaysia. Ultra-Supercritical Coal-Fired Power Plant. Baden, Switzerland.

16. Jansson, C. and Northen, T. (2010). Calcifying cyanobacteria - the potential of biomineralization for carbon capture and storage. Current Opinion Biotechnology, 21(3): 365 - 371.

17. Skjånes, K., Lindblad, P. and Muller J. (2007). $\mathrm{BioCO}_{2}$ - a multidisciplinary, biological approach using solar energy to capture $\mathrm{CO}_{2}$ while producing $\mathrm{H}_{2}$ and high value products. Biomolecular Engineering, 24(4): 405 413.

18. Ramanan, R., Kannan, K., Deshkar, A., Yadav, R. and Chakrabarti T. (2010). Enhanced algal $\mathrm{CO}_{2}$ ) sequestration through calcite deposition by Chlorella sp. and Spirulina platensis in a mini-raceway pond. Bioresource Technology, 101(8): 2616 - 2622.

19. Zhao, L., Chen, Y. and Schaffner, D. W. (2001). Comparison of logistic regression and linear regression in modeling percentage data. Applied and Environmental Microbiology, 67(5): 2129 - 2135.

20. Kargi, F. (2009). Re-interpretation of the logistic equation for batch microbial growth in relation to Monod kinetics. Letters in Applied Microbiology, 48(4): 398 - 401.

21. Xu, Y. and Boeing, W. J. (2014). Modeling maximum lipid productivity of microalgae: Review and next step. Renewable and Sustainable Energy Reviews, 32: 29 - 39.

22. Promega (2010). Wizard Genomic DNA Purification Kit Quick Protocol, FB022. 2010: 1123 - 1126.

23. Simon, N., Campbell, L., Ornolfsdottir, E., Groben, R., Guillou, L., Lange, M. and Medlin, L. K. (2000). Oligonucleotide probes for the identification of three algal groups by dot blot and fluorescent whole-cell hybridization. Journal of Eukaryotic Microbiology, 47(1):76 - 84.

24. Krienitz, L., Ustinova, I., Friedl, T. and Huss V. A. R. (2001). Traditional generic concepts versus $18 \mathrm{~S}$ rRNA gene phylogeny in the green algal family Selenastraceae (Chlorophyceae, Chlorophyta). Journal of Phycology, 37(5): 852 - 865 .

25. Heischkamp, E., Varlik, M., Korkmaz, Ö., Oeljeklaus, G. and Görner K. (2011). Analysis of operating conditions of a flue gas scrubbing process for $\mathrm{CO}_{2}$ separation in a coal-fired power plant. Energy Procedia, 4:1377 - 1384.

26. Ma, S., Chen, G., Guo, M., Zhao, L., Han, T., Zhu, S. (2014). Path analysis on $\mathrm{CO}_{2}$ resource utilization based on carbon capture using ammonia method in coal-fired power Plants. Renewable and Sustainable Energy Reviews, 37: 687 - 697.

27. Shen, Q. H., Gong, Y. P., Fang, W. Z., Bi, Z. C., Cheng, L. H., Xu, X. H. and Chen, H. L. (2015). Saline wastewater treatment by Chlorella vulgaris with simultaneous algal lipid accumulation triggered by nitrate deficiency. Bioresource Technology, 193: 68 - 75.

28. Gerken, H. G., Donohoe, B. Knoshaug, E. P. (2013). Enzymatic cell wall degradation of Chlorella vulgaris and other microalgae for biofuels production. Planta, 237(1): 239 - 253.

29. Nurachman, Z., Hartini, H., Rahmaniyah, W. R., Kurnia, D., Hidayat, R., Prijamboedi, B., Suendo, V., Ratnaningsih, E., Panggabean, L. M. G. and Nurbaiti, S. (2015). Tropical marine Chlorella sp. PP1 as a source of photosynthetic pigments for dye-sensitized solar cells. Algal Research, 10: 25 - 32.

30. Mathimani, T., Uma, L. and Prabaharan D. (2015). Homogeneous acid catalysed transesterification of marine microalga Chlorella sp. BDUG 91771 lipid - An efficient biodiesel yield and its characterization. Renewable Energy, 81: 523 - 533.

31. Imase, M., Watanabe, K., Aoyagi, H. and Tanaka, H. (2008). Construction of an artificial symbiotic community using a Chlorella-symbiont association as a model. FEMS Microbiology Ecology, 63(3): 273 - 282.

32. Borkenstein, C. G., Knoblechner, J., Frühwirth, H. and Schagerl M. (2011). Cultivation of Chlorella emersonii with flue gas derived from a cement plant. Journal of Applied Phycology, 23(1): 131 - 135. 